\title{
How Leader Characteristics and Leader Member Exchange Lead to Social Capital and Job Performance
}

\author{
Duc-Thuan TRAN ${ }^{1}$, Li-Yueh LEE ${ }^{2}$, Phuoc-Thien NGUYEN ${ }^{3}$, Wethima SRISITTIRATKUL ${ }^{4}$
}

Received: July 15, 2019 Revised: September 30, 2019 Accepted: October 09, 2019

\begin{abstract}
The study aims to verify the relationship between leaders' personality traits in leader - member exchange (LMX), and job performance. Hierarchical Regression Analysis was used to examines (a) how leaders' personality traits and LMX affect the influence of social capital on job performance and organizational citizenship behavior; (b) how perceived organization support (POS) can moderate the influences of LMX on social capital, in turn impacting job performance and OCB. Responses are employees in the service industry in Thailand, which consisted of 236 independent samples in 77 groups. Each group included at least one leader and 1-5 followers. The results show that there is a significant relationship between leader's personality traits, LMX and social capital. Leader with the higher level of conscientious, and agreeableness can always create good relations with their followers. The level of LMX are also related to social capital and both of these influence OCB and job performance. The moderating effect of perceived organizational support is also significant that POS can amplify the influence of LMX on social capital. Finally, the research findings show that perceived organizational support is one of the moderating factors in LMX exchanges. Followers perceived organizational support can amplify the influence of LMX on social capital.
\end{abstract}

Keywords : Leaders' Personality Traits, Organizational Citizenship Behavior, Social Capital, Leader Member Exchange, Job Performance

JEL Classification Code : M10, M12, M54

\section{Research Background and Motivation}

With the increasing speed of business, organizations and their employees must be able to quickly and effectively adapt to change. Yet, the 2015 Global Leadership Forecast noted that only 40 percent of Thai leaders consider

1 First Author, Faculty of Economics-Management, Dong Nai Technology University, Vietnam.

Email: tranducthuan@dntu.edu.vn

2 Associate Professor, Department of Business Administration, Kun Shan University, Taiwan. Email: wuleliyu@gmail.com

3 Corresponding Author, Ph.D. Student, Department of Business Administration, Nanhua University, Taiwan. [Postal Address: No. 55, Sec. 1, Nanhua Rd., Dalin Township, Chiayi County 62249, Taiwan (R.O.C.)] Email: nhuanduc08@gmail.com

4 Department of Business Administration, National Cheng Kung University, Taiwan. Email: wethneiw@gmail.com

(c) Copyright: Korean Distribution Science Association (KODISA)

This is an Open Access article distributed under the terms of the Creative Commons Attribution Non-Commercial License (http://Creativecommons.org/licenses/by-nc/4.0/) which permits unrestricted noncommercial use, distribution, and reproduction in any medium, provided the original work is properly cited. themselves effective in leading and managing and successfully introducing change. Therefore, leadership plays a significant role in the organization's ultimate success of the firms (Kaiser, Hogan, \& Craig, 2008). Leaders must have the potential to build a work environment to support followers' creativity in order to overcome strong competition and fluctuation in the work community (Tierney, 2008). In the literature, LMX theory of leadership was developed to explain how leaders can maintain a strong relationship with their followers through the characteristics of leadership (Dansereau, Graen, \& Haga, 1975). Essentially, leaders should be skillful at innovativeness at work to achieve organization goals.

LMX theory is used as a significant tool for examining and predicting the business success of companies. The primary reason is centered on the different dyadic connections amongst leaders and supporters across a range of traits in the defining of in-groups and out-groups. LMX quality has been related to different employee results, for instance job satisfaction, organizational commitment, and 
job performance (Dulebohn, Bommer, Liden, Brouer, \& Ferris, 2012).

Zhang, Wang, and Shi, (2012) characterized theories under which -leaders have the capability to control task assignments and identified the performance of their followers. They considered the impact of likeness and contrasts in the proactive personality traits of the leader and follower dyads on subordinate work results, including effective commitment to the occupation, work execution, work satisfaction, and found that the LMX quality mediates this coordinating. According to social identity theory there is positive relation between OCB and job performance. Cullen, Edwards, Casper, and Gue (2014) found that there is a positive relationship between POS. job performance, and job satisfaction. Consequently, followers that share their goals with the organization will have better performance (Callea, Urbini, \& Chirumbolo, 2016).

In this study we examine the important relationship based on variables, for example, leader - follower relationships, this factor has been identified with leadership style and job performance. However, it has not been analyzed in the relationship between effective leadership and job performance. The LMX quality influences the level of leaders' reciprocity with followers with other resources such as information and the chance to become involved in process of making decisions. High quality LMX are distinguished by elevated requirements with respect to followers' performance, as the result of the leaders' commitment (Breevaart, Bakker, Demerouti, \& van den Heuvel, 2015). There is a relationship between leaders' personality traits and job performance that has been studied for hundreds of years (Barrick \& Mount, 2001).

Though the leader is important in job performance, most research in LMX focuses on the follower's point of view. However, some studies have explored how leaders' personality are related to LMX and job performance (Schyns, 2015). We thus examine how these two characteristics lead to LMX and performance focusing on the leader's point of view as well.

Based on the research background and motivations discussed above, the objectives of the present study are:

1. To understand how LMX mediates the influence of leaders' personality traits on social capital, which further facilitate job performance and OCB.

2. To evaluate how perceived organizational support, and moderate the influence of LMX on social capital.

\section{Literature Review}

\subsection{The Relationship between Follower and Leaders' Personality Traits and LMX}

LMX is a leadership theory which has evolved steadily in recent decades. It is characterized LMX is characterized by the unique relationship between leaders and followers.
The key evidence for the development of LMX theory is that leaders tend to have high quality relationships with only one follower (Erdogan \& Bauer, 2014). Though if leader's personality traits are the center of the characteristics based approach, most studies have examined followers instead of leader personality traits as antecedents of LMX quality (Martin, Guillaume, Thomas, Lee, \& Epitropaki, 2016).

Several personal attributes have been connected to various leadership outcomes (Antonakis \& Day, 2017). Zaccaro et al. (2013) listed 49 attributes which are related to leadership outcomes. According to Miller et al. (2011) all of the Big five traits have a correlation to leader outcomes, especially extraversion and conscientiousness, while agreeableness has a lower correlation with leader outcomes than other traits (Antonakis \& Day, 2017). The relationship between individual personality and leadership status in the in-group relationship is well correlated. The positive correlations between intelligence and extraversion are very important. Effective leaders do have characteristics personality traits that are not for the most part controlled by nonsupervisory. A few people can be effective as leaders in a few circumstances yet not in others (Zaccaro, LaPort, \& José, 2013).

Which personality traits are more inclined to set up and maintain associations with followers? Which ones help leaders build up and maintain associations with numerous followers? Leader agreeableness was fundamentally identified with follower evaluated LMX (Sears \& Hackett, 2011). Previous studies on LMX focus in how followers' personality traits are involved in the advancement of LMX and how personality traits may influence the relationship between leader and followers (Schyns et al., 2012; Judge \& Bono, 2001).

One strategy by which followers can reach their leader's expectations is to focus on regulatory requirements (Henson \& Beehr, 2018). Follower with this approach is close to the leader in the leader-member relationship (Zivnuska, Kacmar, $\&$ Valle, 2017). Though several studies show that follower extraversion is a predictor of LMX, very limited studies focus on leader extraversion (Dulebohn et al., 2012). Moreover, leader extraversion and agreeableness are positively related to LMX quality. Thus, Sear and Hackett (2011) argued that leader agreeableness was used to predict that followers in LMX quality are affected by their enjoyment of the leader.

H1a: Leaders'/ followers' personality traits conscientiousness is positively related to LMX.

H1b: Leaders'/ followers' personality traits extraversion is positively related to LMX.

H1c: Leaders'/ followers' personality traits agreeableness is positively related to LMX. 
H1d: Leaders'/ followers' personality traits openness to experience is positively related to LMX.

H1e: Leaders'/ followers' personality traits emotional stability is positively related to LMX.

\subsection{The Relationship between Leader Member Exchange (LMX) and Social Capital (SC)}

Koopman, Matta, Scott, and Conlon (2015) revealed that participating in other-improvement ingratiation conduct may help workers to build social capital with their leader, and that followers will obtain larger amounts of equity from their leader. They also suggest that leader' evaluation of LMX quality with their follower is an indicator of the procedure. LMX theory specifies that the leader tends to create different relationships with followers which are reciprocal and can strengthen the relationship between leader and follower (Bauer \& Green, 1996). The socioemotional exchange is defined as high LMX, while financial trades is defined as low quality LMX (Dulebohn et al., 2012). Based on the relationship followers should receive important resources from their leaders (Koopman et al., 2015). For the in-group members, who have experience in high quality LMX, there are plentiful exchanges with respect and trust. In-group LMX relationships are concrete whereas, out-group LMX relationships are loose with less interaction and reciprocity (Hau, Kim, Lee, \& Kim, 2013).

Tsai and Ghoshal, (1998) found that social capital has three measurements, including structural, relational, and cognitive social capital. However, in this study, we only focus first two dimensions. Structural social capital means the association between network relations and social which defines who can communicate and makes the relationship successful (Chow \& Chan, 2008). Structural social capital measurement focuses on the general structure of connections inside a social relationship (Zhao, Lu, Wang, Chau, \& Zhang, 2012). For instance, structural social capital may be described by certain supervisors who possess focal positions, or central focuses in the whole group, influencing the network configuration (Ansari, Munir, \& Gregg, 2012).

Relational social capital is the useful side of social capital which alludes to norms sharing and trust between employees in the association (Cabrera \& Cabrera, 2005). Trust is a major factor in networking because trust can determine individual and exchange relationships. Employee who are trustworthy can give social support. People who are highly-trusted have more satisfaction in their work and life. Examples of relational social capital include friendship, family ties, relationships in business, or compatibility with collaborators. Every relationship expresses an alternate level of trust(Ansari et al., 2012).

H2: LMX is positively related to social capital

\subsection{The Relationship between Social capital (SC) and Job Performance (JP)}

Social capital theory suggests that the person to person relationship has the most influence on job performance. Member with higher social capital can encourage association in social networks by making conditions that enhance trust, affinity and friendliness which further facilitate yields positive results (Ellinger et al., 2013).

Ellinger et al., (2013) found that social capital motivates follower behavior. Moreover, the model recommends that the disposition of commitment regarding the organization and the subjective norms of responsibility are related between social capital and performance outcomes.

H3: Social capital has a positive relationship with job performance.

\subsection{The Relationship between Social Capital (SC) and Organizational Citizenship Behavior}

OCB enhances firm functioning by contributing to the development of social capital (Basu, Pradhan, \& Tewari, 2017). Moreover, it is the cooperation, involvement, and selflessness displayed by these people that contributes to the development of trust, affection, and shared understanding between them, which are important aspects of social capital (Lin, 2017; Putnam, 2000). Hence, just as the "good citizens" within a community contribute to the development of social capital within that community. "Good organizational citizens" are likely to be important for the creation of social capital within their organizations (Bolino, Turnley, \& Bloodgood, 2002). Thus, it is reasonable to believe that social capital may result from the willingness of employees to exceed their formal job requirements in order to help each other, to subordinate their individual interests for the good of the organization, and to take a genuine interest in the organization's activities and overall goals. Thus, the following hypothesis is developed:

H4: Social capital is positively related to OCB

\subsection{The Relationship between Perceived Organizational Support (POS), Leader Member Exchange (LMX) and Social Capital (SC)}

This study focused on interpersonal trust in the leadermember relationship. POS denotes how much trust the organization has in its employees and how much support and help it gives them. Several studies observe that POS influences leader to trust and support and that there is a positive relationship between trust in social capital and POS (Ristig, 2009). Rhoades and Eisenberger (2002) found that follower perception that their leader is concerned with their well-being and welfare leads to POS. They also found that 
followers share ideals with the leader because they think that their leader is represent the organization, suggesting that follower LMX is led to POS (Eisenberger et al., 2014).

High LMX quality shows that followers have a good value to the organization and leader. It may be argued that using only the follower point of view to rate leaders as representative of the organization has is problematic. Thus, we also focus on how leaders see their followers as agents of the company as well as how they respond in POS by the construction of high LMX quality relationships with followers. Support of the leader is more strongly related to POS than support by followers (Thomas, 2008). Thus, followers should have a strong inclination to identify leaders with the organization. Eisenberger et al. (2014) argued that of the leaders and followers all perceive higher levels of POS, then the influence of LMX on social capital will be strengthened. In the other words, POS will facilitate and accelerate the influence of LMX on social capital. The magnitude of the influence from LMX to social capital will be significantly higher POS group than the lower one. Based on the above discussion, the following hypothesis is developed:

H5: POS moderates the relationship between LMX and social capital.

\section{Research Design and Methodology}

\subsection{The Conceptual Framework}

The main purpose of the present study is to clarify how POS and OCB affect the moderator role of LMX quality and social capital, in turn leading to job performance. The framework is shown in Figure 1.

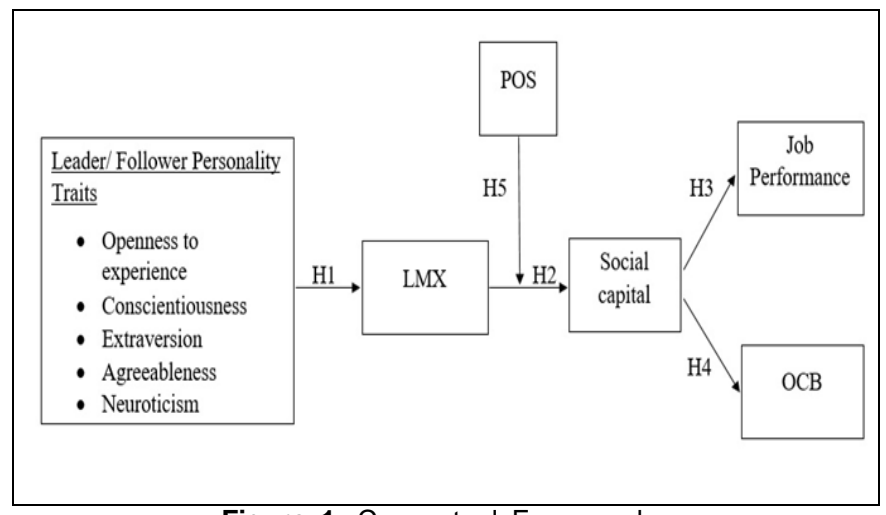

Figure 1: Conceptual Framework

\subsection{Questionnaire Design and Construct Measurement}

There are six main constructs as shown in the conceptual model as shown in Figure 1. The independent variables are leader's personality traits and followers'. Job performance and OCB are two of the dependent variables. The Five-point Likert scale was used to score all items in the constructs ranging from $1=$ strongly disagree to $5=$ strongly agree.

Discrete variables which cannot be measured using a Likert scale, such as age, gender, and demographic variables were shown in the last section of the questionnaire.

LMX quality was measured by 7 items question drawn from Graen and Uhl-Bien (1995). Leader's personality traits and followers' were measured using the big five personality traits question items adapted from Barrick and Mount (1991). Perceived organizational support was measured by using question items adapted from Liden and Maslyn (2000). Social capital was measured by four factors: trust, commitment, structural SC, and relational SC using question items adapted from Chow and Chan (2008) and Nahapiet and Goshal (1998). Job performance was measured by using question items from Shih, Chiang and Hsu (2013). OCB was measured by using question items adapted from Organ (1988).

\subsection{Sampling Plan and Data Collection Procedure}

The questionnaires were distributed to 300 participants including leaders and followers in the same team using a paper questionnaire. The survey was taken in Thailand and the sample are Thais working in the service industry. The respondents were asked to indicate their agreement on a 1-5 Likert scale ranging from "strongly agree" to "strongly disagree". The authors first contacted the human resource managers and upon their agreement, these managers distributed the leader questionnaires to leaders and follower questionnaire to followers. These managers were responsible for collecting all questionnaires to avoid bias. The names of the respondents were not mentioned to protect respondent privacy (Yeo \& Ananthram, 2008).

\section{Research Results and Discussions}

\subsection{Descriptive Analysis}

The survey questionnaire was delivered in both Thai and English version. Among 300 participants, 236 were valid, creating a response rate of $78.7 \%$. Each group includes one leader and 1-5 followers. Eventually, this study obtained 77 answers from the leaders and 159 from followers. The data were collected through an anonymous survey utilizing questionnaires, participation was voluntary, and responses remained anonymous and confidential.

The demographic attributes of the respondents collected in this study include: Gender, Age, Education level, Occupation level, Working Experience and Income/month. Table 1 shows that $77.54 \%$ of the respondents are female and $22.46 \%$ are male. Respondents age 20-25 years old, 26- 
30 years, 31-35 years and Over 35 years' old were $23.73 \%$, $36.44 \%, 10.17 \%$, and $29.66 \%$ respectively. Around $73 \%$ of respondents have an undergraduate degree, following by postgraduate $18.23 \%$ while the remaining $8.89 \%$ have high school or below educational levels. $67.38 \%$ of respondents were followers and $32.62 \%$ were Leaders. Approximately $42.38 \%$ of the respondents had at least 5 years of work experience while $16.10 \%$ had $1-3$ years' experiences. Only $1.28 \%$ of the respondents earned more than 50,000 $\mathrm{THB} /$ month whereas $43.22 \%$ earned $10,001-20,000$ THB/month.

Table 1: Demographic Characteristics of Respondents

\begin{tabular}{|l|l|c|c|}
\hline $\begin{array}{c}\text { Charac- } \\
\text { teristic }\end{array}$ & \multicolumn{1}{|c|}{ Categories } & Frequency & $\begin{array}{c}\text { Percentage } \\
(\%)\end{array}$ \\
\hline \multirow{3}{*}{ Gender } & Male & 53 & 22.46 \\
\cline { 2 - 4 } & Female & 183 & 77.54 \\
\hline \multirow{4}{*}{ Age } & $20-25$ years & 56 & 23.73 \\
\cline { 2 - 4 } & $26-30$ years & 86 & 36.44 \\
\cline { 2 - 4 } & $31-35$ years & 24 & 10.17 \\
\cline { 2 - 4 } & Over 35 years old & 70 & 29.66 \\
\hline \multirow{3}{*}{$\begin{array}{l}\text { Education } \\
\text { Level }\end{array}$} & < undergraduate & 21 & 8.89 \\
\cline { 2 - 4 } & undergraduate & 172 & 72.88 \\
\cline { 2 - 4 } & Postgraduate & 43 & 18.23 \\
\hline Occupation & Leader & 77 & 32.62 \\
\cline { 2 - 4 } Level & Follower & 159 & 67.38 \\
\hline \multirow{3}{*}{$\begin{array}{l}\text { Work } \\
\text { Experience }\end{array}$} & $<1$ year & 51 & 21.61 \\
\cline { 2 - 4 } & $1-3$ years & 38 & 16.10 \\
\cline { 2 - 4 } & $3-5$ years & 47 & 19.91 \\
\cline { 2 - 4 } & $>5$ years & 100 & 42.38 \\
\hline \multirow{3}{*}{$\begin{array}{l}\text { Income } \\
\text { /month }\end{array}$} & $10,001-20,000$ & 102 & 43.22 \\
\cline { 2 - 4 } (THB) & $20,001-30,000$ & 87 & 36.86 \\
\cline { 2 - 4 } & $30,001-40,000$ & 17 & 7.2 \\
\cline { 2 - 4 } & $40,001-50,000$ & 27 & 11.44 \\
\cline { 2 - 4 } & $>50,000$ & 3 & 1.28 \\
\hline
\end{tabular}

H3: Board member average ages are positively associated with financial leverage.

\subsection{Confirmatory Factor Analysis (CFA)}

This study includes confirmatory factor analysis (CFA) using AMOS22 and SPSS23 to test correlations of variables among constructs. The CFA is used to check to construct validity, which consists of these components: factor loading, composite reliability (CR), and average variance extracted (AVE). Following Hair et al., (2011), this study adopts the following criteria: factor loading $>0.6$ or higher, composite reliability (CR) $>0.7$ or higher and average variance extracted (AVE) $>0.5, \mathrm{CR}$ and AVE are calculated using the following formulas:

$$
C R=\frac{\left(\sum \lambda_{i}\right)^{2}}{\left(\sum \lambda_{i}\right)^{2}+\left(\sum \epsilon_{i}\right)}
$$

Where:

$\lambda=$ standardized factor loading

$i=$ number of items

$n=$ for $\mathrm{n}$ items (Total number of items)

$\varepsilon i=$ variance of the error of items

$$
\operatorname{AVE}=\frac{\sum_{i=1}^{k} \lambda_{i}^{2}}{\sum_{i=1}^{k} \lambda_{i}^{2}+\sum_{i=1}^{k} \operatorname{Var}\left(e_{i}\right)}
$$

Where:

$k$ is the number of items

$\lambda_{i}$ is the factor loading of item $i$

$\operatorname{Var}\left(\mathrm{e}_{\mathrm{i}}\right)$ is the variance of the error of item $\mathrm{i}$

Following Hair et al., (2010), this study identify four criteria for the evaluation of model fit: (1) Goodness of Fit Index (GFI) >0.90, (2) Chi-squared/d.f <3.00, (3) Comparative Fit Index (CFI) $>0.95$, and (4) Root Mean Square of Standardized Residual (RMSEA) $<0.08$. With CR $>0.6$; $\mathrm{AVE}>0.5$, the model fit for all the constructs is shown in table 2 below:

\begin{tabular}{|c|c|c|c|c|}
\hline Research Variables & Items code & Factor Loading & CR & AVE \\
\hline \multicolumn{5}{|l|}{ Leader's Personality Traits } \\
\hline Extraversion & Exs & $0.845^{\star * *}$ & \multirow{3}{*}{0.864} & \multirow{3}{*}{0.613} \\
\hline Openness to Experience & Ops & $0.768^{\star * *}$ & & \\
\hline Neuroticism & Nus & $0.765^{\star * \star}$ & & \\
\hline \multicolumn{5}{|l|}{ Follower LMX } \\
\hline My working relationship with my leader is effective. & fLMX2 & $0.708^{* *}$ & \multirow{5}{*}{0.917} & \multirow{5}{*}{0.623} \\
\hline $\begin{array}{l}\text { I have enough confidence in my leader that I would defend and } \\
\text { justify his/her decisions if he or she were not present to do so. }\end{array}$ & fLMX3 & $0.538^{* * *}$ & & \\
\hline My leader considers my suggestions for change. & fLMX4 & $0.765^{\star \star \star}$ & & \\
\hline My leader and I are suited to each other. & fLMX5 & $0.987^{\star \star *}$ & & \\
\hline My leader understands my problems and needs. & fLMX6 & $0.922^{\star \star \star}$ & & \\
\hline
\end{tabular}

Table 2: CFA Model Fit Results 


\begin{tabular}{|c|c|c|c|c|}
\hline \multicolumn{5}{|l|}{ Perceived Organization Support } \\
\hline My organization values my contribution to its well-being. & POS1 & $0.829^{\star \star *}$ & \multirow{5}{*}{0.930} & \multirow{5}{*}{0.690} \\
\hline $\begin{array}{l}\text { My organization would understand a long absence due to my } \\
\text { illness. }\end{array}$ & POS3 & $0.708^{\star * *}$ & & \\
\hline My organization really cares about my well-being. & POS4 & $0.848^{\star * *}$ & & \\
\hline $\begin{array}{l}\text { My organization is willing to extend itself in order to help me } \\
\text { perform my job to the best of my ability. }\end{array}$ & POS5 & $0.834^{\star * *}$ & & \\
\hline My organization takes pride in my accomplishments at work. & POS6 & $0.854^{\star \star \star}$ & & \\
\hline Structural Social capital & SSC & $0.751^{\star \star \star}$ & \multirow[t]{2}{*}{0.642} & \multirow[t]{2}{*}{0.578} \\
\hline Relational Social capital & RSC & $0.568^{\star \star \star}$ & & \\
\hline \multicolumn{5}{|l|}{ Job Performance } \\
\hline My followers are capable of meeting job objectives. & JP1 & $0.586^{\star \star \star}$ & \multirow{2}{*}{0.800} & \multirow{2}{*}{0.505} \\
\hline My followers are confident in his/her technical competence. & JP2 & $0.637^{\star \star \star}$ & & \\
\hline
\end{tabular}

Table 2 shows that results of the items in the team level analysis satisfy with the threshold of the previous study. The standardized factor loadings of all items are higher than 0.6, which show that they truly represent these constructs sufficiently. The $\mathrm{CR}$ values are greater than 0.7 , which indicates good reliability. Furthermore, AVE values are higher than 0.5 , indicating the reliability and validity of all constructs.

\subsection{Hierarchical Regression Analysis}

Hierarchical Regression Analysis is applied for testing the hypotheses. We first tested the relationship between the Leader's Personality Traits (conscientiousness, extraversion, agreeableness, openness to experience, neuroticism), and follower LMX (H1). We then tested the relationship between fLMX and social capital (H2), the relationship between social capital and job performance (H3), the relationship between social capital and OCB (H4) and the moderating effect of perceived organizational support on the relationship between LMX and social capital (H5). The results are shown in Table 2, which indicate that conscientiousness, $(\beta=0.345$, $\mathrm{p}<0.001), \quad$ extroversion $\quad(\beta=0.395, \quad \mathrm{p}<0.001) \quad$ and agreeableness $(\beta=0.401, p<0.001)$ have a significant effect on LMX, and this LMX also serves as partial mediators to facilitate the influence of three antecedents on social capital $(\beta=0.146-0.362, \quad p<0.001) \quad$ and LMX $(\beta=0.338-0.496$, $\mathrm{p}<0.001)$. Therefore, hypotheses $\mathrm{H} 2$, and $\mathrm{H} 1 \mathrm{a}-\mathrm{H} 3 \mathrm{c}$ are supported. However, openness to experience $(\beta=0.030$, $\mathrm{p}<0.05)$ and Neuroticism $(\beta=-0.156, \mathrm{p}<0.05)$ do not show any significant influence on LMX. Thus, no mediation effect of these two antecedents was found. Therefore, hypotheses H1d-H1e, are not supported.

Furthermore, the results shown in Table 3 indicate that social capital does not have a significant influence on job performance $(\beta=0.057, \mathrm{p}<0.05$. It does have a significant influence on organizational citizenship behavior $(\beta=0.471$, $\mathrm{p}<0.001)$. Therefore, hypothesis $\mathrm{H} 3$ is not supported, while hypothesis $\mathrm{H} 4$ is supported. For the interaction effect of LMX and POS on social capital, in addition to the effect of $\operatorname{LMX}(\beta=0.464, p<0.001)$, and POS $(\beta=0.241, p<0.001)$, the moderating effect of POS on social capital is also significant ( $\beta=0.194, p<0.01)$. Therefore, hypothesis H5 is supported.

Table 3: Results of the Hierarchical Regression Analysis

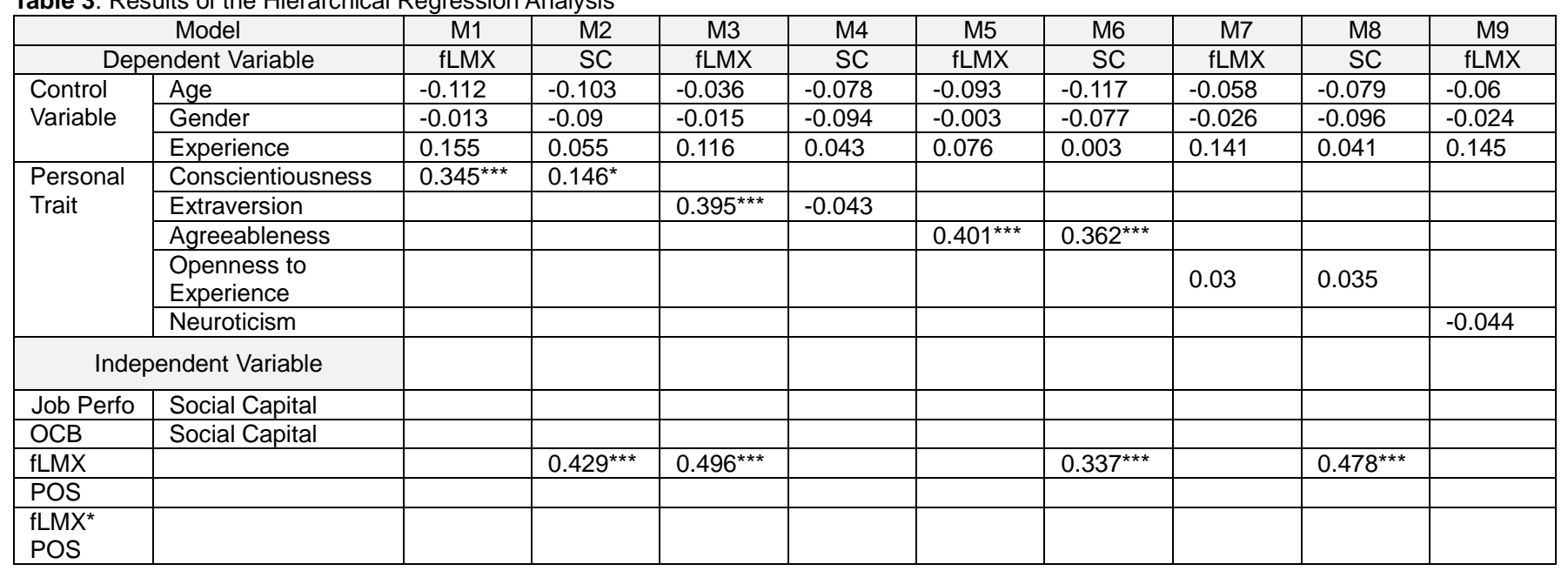




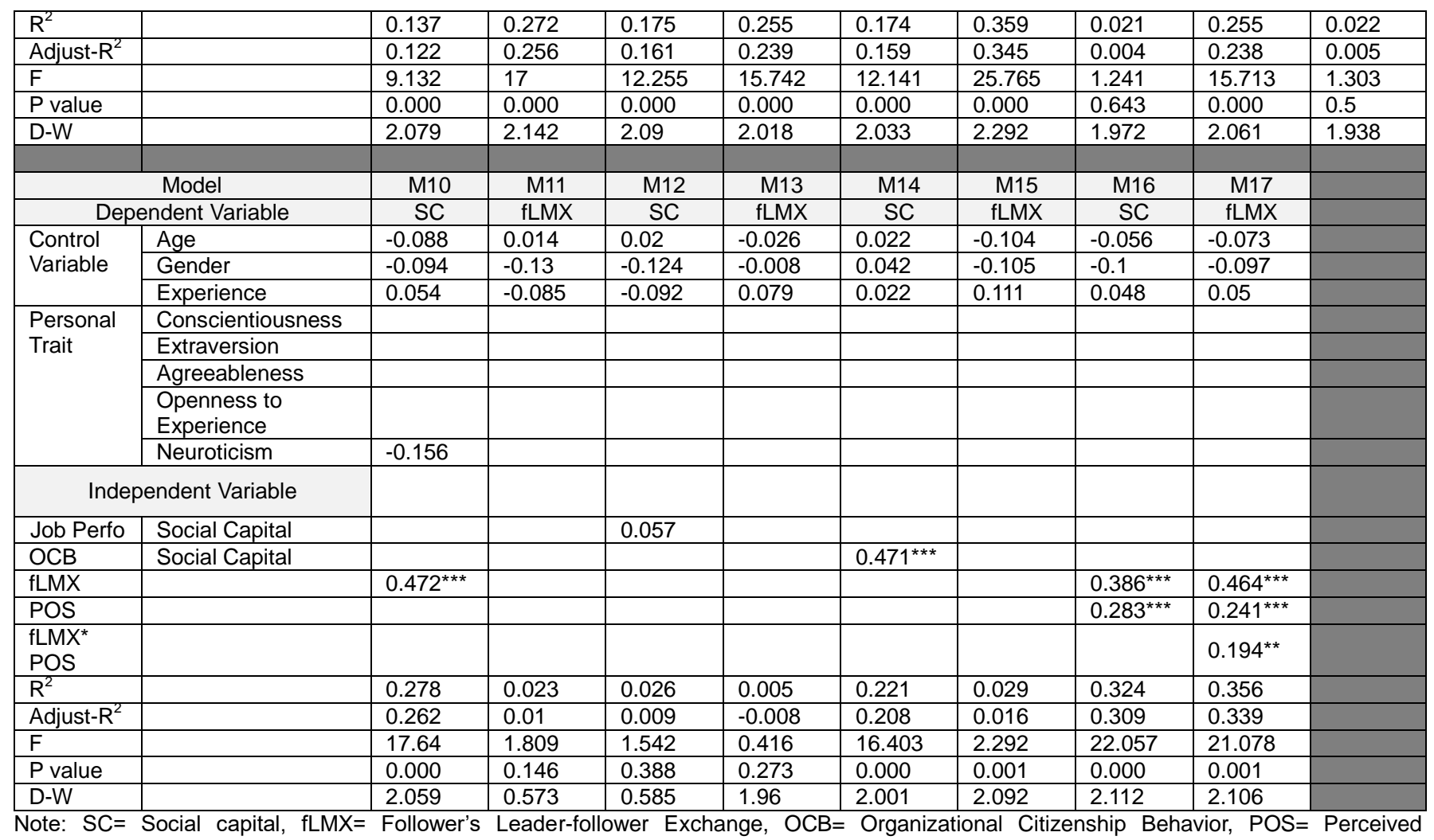

Organizational Support.

\section{Conclusion and Suggestions}

\subsection{Research Conclusions}

This study explores the Leader-Follower dyad influence on team level Job Performance. Several conclusions could be drawn from the results of this study:

First, although big five personality characteristics of leader and members are critical for job performance (Camps et al., 2016), few limited studies focus on the Big Five traits together with LMX (Dulebohn et al., 2012). The study showed that the effect of leader's personality traits of conscientiousness, extraversion and agreeableness is related to LMX. According to Wolff and Kim, (2012) conscientiousness is the most generally inspected attributes among all the big five identity measurements and both conscientiousness and agreeableness are positively related to personal concern. Leaders with high agreeableness are affable, kind, always support their followers (Deinert et al., 2015), and always create good relationship with their followers. Schyns et al. (2012) found that leaders' agreeableness as identified by the followers affects LMX. Follower LMX is positively related to Social capital. According to Koopman et al., (2015) the relationship between followers and leaders will be higher when followers obtain important resources from their leaders. Thus, LMX is positively related to social capital and LMX mediates the relationship between social capitals.

In addition, social capital theory is concerned with the strength of relationships between employees and people in the team and organization (Yang et al., 2011) and Social capital is a quality created between people. Though Ellinger et al., (2013) found that social capital motivates follower behavior the disposition of commitment regarding the organization and the subjective norm of responsibility are related between social capital and performance outcomes. However, there is very few studies consider social capital as an organizational resource with positive outcomes, whereas others increasingly consider both positive and negative outcomes (Basu et al., 2017). AbuAlRub (2004) found that the relationship between social capital and job performance among workers with higher performance tended to be significantly higher. They found a nonlinear relationship between Social Capital and Job Performance with an inverted U-shaped relationship (Kraimer, Seibert, \& Astrove, 2015). These research results may indicate that, when the social capital is low, increases in social capital will significantly influence job performance through the mechanisms of coordination, communication and integration.

However, when social capital becomes too high, the exercise of coordination and integration will be significantly reduced. At this point, innovation and continuous improvement capability will be significantly reduced. Therefore, beyond a certain level, increases in social capital will actually reduce the level of job performance. This may be the reason for the finding of no insignificant relationship between social capital and job performance.

Furthermore, the results show that there is a significant 
relationship between social capital and organization citizenship behavior. Leaders should improve the policy of participative management system and exercise of the delegation of authority to subordinate within the organization. In this way, motivation and cooperation in the organization will improve and organizational efficiency will increase.

Finally, the research findings show that perceived organizational support is one of the moderating factors in LMX exchanges. Followers perceived organizational support can amplify the influence of LMX on social capital.

\subsection{Research Implication and Contributions}

\subsubsection{Academic Implication}

This paper provides a useful approach to showing how leader characteristics influence LMX and social capital which further facilitate job performance. However, as mentioned in the discussion social capital may produce internal conflict. The results may provide a guide for further study to identify the relationships between conscientiousness, extraversion, and agreeableness.

\subsubsection{Managerial Implication}

With the fierce competition nowadays not only for business but also for talent acquisition it is important for companies to search for ways of obtaining and retaining talent in the company by recognizing their preferences and needs. Managers must coordinate other people and put the right people together to develop opportunities. Social capital is more valuable to a manager with few peers. A manager's ability to develop follower's opportunities is constrained by the presence of one or more peers in a position to undercut or denigrate the manager's proposals. Managers have to figure out how best to perform the job, which sometimes depends on getting others to accept the manager's definition of the job. The value of social capital decreases with an increasing number of people doing the same work. Therefore, exercising such a level of influence on internal relationships in the organization and the number of people in the team may break or decrease performance. The manager should consider the number of people and other factors to increase job performance.

\subsection{Research Limitation}

This study has several limitations. First, there are sampling constraints. Since the method used for sampling was convenience sampling, the respondents had varied characteristics. Second, since most of the questionnaires were distributed during working hours, the respondents may have had less time to spare to answer the questions. Third, the survey was collected in one language and one country and not a specific industry in order to avoid bias. The original purpose is to study the relationships between leaders and followers in the same industry. Future research can extend these research results to different industries in different countries.

\section{References}

AbuAlRub, R. F. (2004). Job stress, job performance, and social support among hospital nurses. Journal of Nursing Scholarship, 36(1), 73-78.

Ansari, S., Munir, K., \& Gregg, T. (2012). Impact at the 'bottom of the pyramid': The role of social capital in capability development and community empowerment. Journal of Management Studies, 49(4), 813-842.

Antonakis, J., \& Day, D. V. (Eds.). (2017). The nature of leadership. Thousand Oaks, CA: Sage publications.

Arregle, J. L., Hitt, M. A., Sirmon, D. G., \& Very, P. (2007). The development of organizational social capital: Attributes of family firms. Journal of Management Studies, 44(1), 73-95.

Bauer, T. N., \& Green, S. G. (1996). Development of leadermember exchange: A longitudinal test. Academy of Management Journal, 39(6), 1538-1567.

Barrick, M. R., Mount, M. K., \& Judge, T. A. (2001). Personality and performance at the beginning of the new millennium: What do we know and where do we go next?. International Journal of Selection and Assessment, 9(1-2), 9-30.

Barrick, M. R., \& Mount, M. K. (1991). The big five personality dimensions and job performance: A metaanalysis. Personnel Psychology, 44(1), 1-26.

Basu, E., Pradhan, R. K., \& Tewari, H. R. (2017). Impact of organizational citizenship behavior on job performance in Indian healthcare industries: The mediating role of social capital. International Journal of Productivity and Performance Management, 66(6), 780-796.

Breevaart, K., Bakker, A. B., Demerouti, E., \& van den Heuvel, M. (2015). Leader-member exchange, work engagement, and job performance. Journal of Managerial Psychology, 30(7), 754-770.

Bolino, M. C., Turnley, W. H., \& Bloodgood, J. M. (2002). Citizenship behavior and the creation of social capital in organizations. Academy of Management Review, 27(4), 505-522.

Cabrera, E. F., \& Cabrera, A. (2005). Fostering knowledge sharing through people management practices. The International Journal of Human Resource Management, 16(5), 720-735.

Callea, A., Urbini, F., \& Chirumbolo, A. (2016). The mediating role of organizational identification in the relationship between qualitative job insecurity, OCB and job performance. Journal of Management Development, 35(6), 735-746.

Camps, J., Oltra, V., Aldás-Manzano, J., Buenaventura-Vera, G., \& Torres-Carballo, F. (2016). Individual performance in turbulent environments: The role of organizational learning capability and employee flexibility. Human 
Resource Management, 55(3), 363-383.

Chow, W. S., \& Chan, L. S. (2008). Social network, social trust and shared goals in organizational knowledge sharing. Information \& Management, 45(7), 458-465.

Cohen, D., \& Prusak, L. (2001). In good company: how social capital makes organizations work. Boston, MA: Harvard Business School Press.

Costa Jr, P. T., \& McCrae, R. R. (1992). Four ways five factors are basic. Personality and Individual Differences, 13(6), 653-665.

Cullen, K. L., Edwards, B. D., Casper, W. C., \& Gue, K. R. (2014). Employees' adaptability and perceptions of change-related uncertainty: Implications for perceived organizational support, job satisfaction, and performance. Journal of Business and Psychology, 29(2), 269-280.

Dansereau Jr, F., Graen, G., \& Haga, W. J. (1975). A vertical dyad linkage approach to leadership within formal organizations: A longitudinal investigation of the role making process. Organizational Behavior and Human Performance, 13(1), 46-78.

Deinert, A., Homan, A. C., Boer, D., Voelpel, S. C., \& Gutermann, D. (2015). Transformational leadership subdimensions and their link to leaders' personality and performance. The Leadership Quarterly, 26(6), 10951120.

Dulebohn, J. H., Bommer, W. H., Liden, R. C., Brouer, R. L., \& Ferris, G. R. (2012). A meta-analysis of antecedents and consequences of leader-member exchange: Integrating the past with an eye toward the future. Journal of Management, 38(6), 1715-1759.

Eisenberger, R., Shoss, M. K., Karagonlar, G., GonzalezMorales, M. G., Wickham, R. E., \& Buffardi, L. C. (2014). The supervisor POS-LMX-subordinate POS chain: Moderation by reciprocation wariness and supervisor's organizational embodiment. Journal of Organizational Behavior, 35(5), 635-656.

Ellinger, A. E., Musgrove, C. C. F., Ellinger, A. D., Bachrach, D. G., Baş, A. B. E., \& Wang, Y. L. (2013). Influences of organizational investments in social capital on service employee commitment and performance. Journal of Business Research, 66(8), 1124-1133.

Erdogan, B., \& Bauer, T. N. (2014). Leader-member exchange (LMX) theory: The relational approach to leadership. In D. V. Day (Ed.), Oxford library of psychology. The Oxford handbook of leadership and organizations (pp. 407-433). New York, NY: Oxford University Press.

Graen, G. B., \& Uhl-Bien, M. (1995). Relationship-based approach to leadership: Development of leader-member exchange (LMX) theory of leadership over 25 years: Applying a multi-level multi-domain perspective. The Leadership Quarterly, 6(2), 219-247.

Hau, Y. S., Kim, B., Lee, H., \& Kim, Y. G. (2013). The effects of individual motivations and social capital on employees' tacit and explicit knowledge sharing intentions. International Journal of Information
Management, 33(2), 356-366.

Henson, J. A., \& Beehr, T. (2018). Subordinates' core selfevaluations and performance predict leader-rated LMX. Leadership \& Organization Development Journal, 39(1), 150-168.

Ilies, R., Nahrgang, J. D., \& Morgeson, F. P. (2007). Leadermember exchange and citizenship behaviors: A metaanalysis. Journal of Applied Psychology, 92(1), 269-277.

Ireland, R. D., Hitt, M. A., \& Vaidyanath, D. (2002). Alliance management as a source of competitive advantage. Journal of Management, 28(3), 413-446.

Judge, T. A., \& Bono, J. E. (2001). Relationship of core selfevaluations traits - self-esteem, generalized self-efficacy, locus of control, and emotional stability — with job satisfaction and job performance: A metaanalysis. Journal of Applied Psychology, 86(1), 80-92.

Kaiser, R. B., Hogan, R., \& Craig, S. B. (2008). Leadership and the fate of organizations. American Psychologist, 63(2), 96-110.

Koopman, J., Matta, F. K., Scott, B. A., \& Conlon, D. E. (2015). Ingratiation and popularity as antecedents of justice: A social exchange and social capital perspective. Organizational Behavior and Human Decision Processes, 131, 132-148.

Kraimer, M. L., Seibert, S. E., \& Astrove, S. L. (2015). 14 high LMX: Career mobility and success. In: Talya N. Bauer and Berrin Erdogan (Eds), The Oxford Handbook of Leader-Member Exchange. DOI: 10.1093/oxfordhb/9780199326174.013.0005

Lin, N. (2017). Building a network theory of social capital. In Social capital (pp. 3-28). New York, NY: Routledge.

Liden, R. C., \& Maslyn, J. M. (1998). Multidimensionality of leader-member exchange: An empirical assessment through scale development. Journal of Management, 24(1), 43-72.

Liden, R. C., Sparrowe, R. T., \& Wayne, S. J. (1997). Leader-member exchange theory: The past and potential for the future. Research in Personnel and Human Resources Management, 15, 47-120.

Martin, R., Guillaume, Y., Thomas, G., Lee, A., \& Epitropaki, O. (2016). Leader-member exchange (LMX) and performance: A meta-analytic review. Personnel Psychology, 69(1), 67-121.

Miller, J. D., Hoffman, B. J., Gaughan, E. T., Gentile, B., Maples, J., \& Keith Campbell, W. (2011). Grandiose and vulnerable narcissism: A nomological network analysis. Journal of Personality, 79(5), 1013-1042.

Nahapiet, J., \& Ghoshal, S. (1998). Social capital, intellectual capital, and the organizational advantage. The Academy of Management Review, 23(2), 242-266.

Organ, D. W. (1988). A restatement of the satisfactionperformance hypothesis. Journal of Management, 14(4), 547-557.

Putnam, R. D. (2000). Bowling alone: America's declining social capital. In Culture and politics (pp. 223-234). New York, NY: Palgrave Macmillan.

Rhoades, L., \& Eisenberger, R. (2002). Perceived 
organizational support: A review of the literature. Journal of Applied Psychology, 87(4), 698-714. http://dx.doi.org/10.1037/0021-9010.87.4.698

Ristig, K. (2009). The impact of perceived organizational support and trustworthiness on trust. Management Research News, 32(7), 659-669.

Schyns, B. (2015). Leader and follower personality and LMX. In: Talya N. Bauer and Berrin Erdogan (eds), The Oxford Handbook of Leader-Member Exchange, 119. DOI: 10.1093/oxfordhb/9780199326174.013.0016

Schyns, B., Maslyn, J. M., \& van Veldhoven, M. P. (2012). Can some leaders have a good relationship with many followers? The role of personality in the relationship between leader-member exchange and span of control. Leadership \& Organization Development Journal, 33(6), 594-606.

Sears, G. J., \& Hackett, R. D. (2011). The influence of role definition and affect in LMX: A process perspective on the personality-LMX relationship. Journal of Occupational and Organizational Psychology,84(3), 544-564.

Shih, H. A., Chiang, Y. H., \& Hsu, C. C. (2013). High performance work system and HCN performance. Journal of Business Research, 66(4), 540-546.

Tekleab, A. G., Takeuchi, R., \& Taylor, M. S. (2005). Extending the chain of relationships among organizational justice, social exchange, and employee reactions: The role of contract violations. Academy of Management Journal, 48(1), 146-157.

Thomas, R. J. (2008). Crucibles of leadership: How to learn from experience to become a great leader. Cambridge, MA: Harvard Business Press.

Tierney, P. (2008). Leadership and employee creativity. In: J. Zhou and C. E. Shalley (eds), Handbook of
Organizational Creativity (pp. 95-123). New York, NY: Lawrence Erlbaum Associates.

Tsai, W., \& Ghoshal, S. (1998). Social capital and value creation: The role of intrafirm networks. Academy of Management Journal, 41(4), 464-476.

Yang, J., Gong, Y., \& Huo, Y. (2011). Proactive personality, social capital, helping, and turnover intentions. Journal of Managerial Psychology, 26(8), 739-760.

Yeo, M., \& Ananthram, S. (2008). A test of four western scales in a Singaporean service organisation. Research and Practice in Human Resource Management, 16(2). https://www.questia.com/read/1G1-200117636/a-test-offour-western-scales-in-a-singaporean-service

Zaccaro, S. J., LaPort, K., \& José, I. (2013). The attributes of successful leaders: A performance requirements approach. In: Michael G. Rumsey (ed.), The Oxford Handbook of Leadership. 10.1093/oxfordhb/9780195398793.013.0002

Zhang, Z., Wang, M. O., \& Shi, J. (2012). Leader-follower congruence in proactive personality and work outcomes: The mediating role of leader-member exchange. Academy of Management Journal, 55(1), 111-130.

Zhao, L., Lu, Y., Wang, B., Chau, P. Y., \& Zhang, L. (2012). Cultivating the sense of belonging and motivating user participation in virtual communities: A social capital perspective. International Journal of Information Management, 32(6), 574-588.

Zivnuska, S., Kacmar, K. M., \& Valle, M. (2017). The mechanisms of regulatory focus: Mindfulness, leadermember exchange, and motivational outcomes. Career Development International, 22(1), 37-49.

Wolff, H. G., \& Kim, S. (2012). The relationship between networking behaviors and the big five personality dimensions. Career Development International, 17(1), 43-66. 